\title{
EXPERIMENTAL IDENTIFICATION AND SELECTION OF DYNAMIC PROPERTIES OF A HIGH-SPEED TRACKED VEHICLE SUSPENSION SYSTEM
}

\section{IDENTYFIKACJA DOŚWIADCZALNA ORAZ DOBÓR CECH DYNAMICZNYCH UKŁADU JEZDNEGO SZYBKOBIEŻNEGO POJAZDU GĄSIENICOWEGO*}

\begin{abstract}
The material diversity of subassemblies making up the tracked vehicle suspension system and the system wear level make it difficult to determine the value of forces acting in it. This paper presents a manner in which parameters of the model of a highspeed tracked vehicle suspension system can be adjusted using the genetic algorithm optimization method. The vehicle motion is tested experimentally to find reference characteristics of kinematic quantities of the system selected points. The simulation results obtained from numerical analyses are presented in charts and compared to the results of experimental testing. Finally, damping values in the vehicle shock-absorbers are determined based on an adopted criterion.
\end{abstract}

Keywords: tracked vehicle suspension, identification of suspension properties, multibody dynamics, genetic algorithms.

\begin{abstract}
Zróżnicowanie materiałowe podzespołów wchodzacych w skład gąsienicowego układu jezdnego oraz stopień jego zużycia wpływaja na trudność określenia wartości sit działających w tym układzie. W artykule poprzez zastosowanie metody optymalizacji algorytmami genetycznymi, przedstawiono sposób dostosowania parametrów modelu układu zawieszenia szybkobieżnego pojazdu gasienicowego. Przeprowadzono badania doświadczalne ruchu pojazdu, w celu wyznaczenia charakterystyk wielkości kinematycznych wybranych punktów układu, które zostały przyjęte jako referencyjne. W rezultacie przeprowadzonych analiz otrzymano wyniki symulacji numerycznych, które zestawiono na wykresach i porównano z wynikami badań doświadczalnych. W końcowym etapie na podstawie przyjętego kryterium określono wartości tlumienia w amortyzatorach pojazdu.
\end{abstract}

Stowa kluczowe: zawieszenie pojazdu gąsienicowego, identyfikacja własności zawieszenia, metoda układów wieloczłonowych, algorytmy genetyczne.

\section{Introduction}

The design and modification of the tracked vehicle suspension system is now supported with the vehicle motion numerical simulations based on the principles of multibody dynamics. Such analyses make it possible to reduce experimental testing costs and shorten the time of the new product commercialization. In terms of the vehicle motion nature simulation, it is essential to take account of the impact of the track on the suspension system as this enables precise selection of the suspension components.

A conventional tracked vehicle suspension system incorporates not only metal elements but also bushings made of rubber or other materials [17]. The material diversity of subassemblies and the vehicle operation time make it difficult to determine the forces acting in the track segments. A change in parameters describing the phenomena occurring in this area (cf. Fig. 1) has a direct effect on the performance of the vehicle entire suspension system.

The system properties are also affected by the track wear level, which is difficult to assess. Depending on the manufacturer, the track service life is estimated at the level of about 2000 $\mathrm{km}$. The environment of the track system operation is another significant factor. For example, high air dustiness increases the intensity of wear [9].

According to [2], the forces occurring in the track system can be identified through testing carried out on a test stand. A method of the track tension determination in real time is presented in [14]. The method finds application in active suspen- sion systems. Identification of the properties of damping elements of the tracked vehicle suspension with the use of neural networks is presented in [21,22].

Sankar et al. [20] and Dhir \& Sankar [7] developed a model for dynamic simulation of tracked vehicles with independent suspension, offering the possibility of using linear or nonlinear characteristics of spring and damping elements. A numerical simulation in the time domain makes it possible to improve the crew's comfort and safety by observing the suspension system performance. In [18], optimization of the suspension system spring elements is taken into consideration, adopting the criterion of minimization of the driver's seat vertical acceleration values during 8-hour exposure to vibrations. Gregory M. Hulbert et al. [10] developed a method of the rocker design optimization using characteristics of the forces acting on the suspension node which are obtained from the vehicle simulation. In [16], the methodology of modelling hybrid drive systems and elements of the tracked vehicle suspension is presented. Choi et al. [6] present the

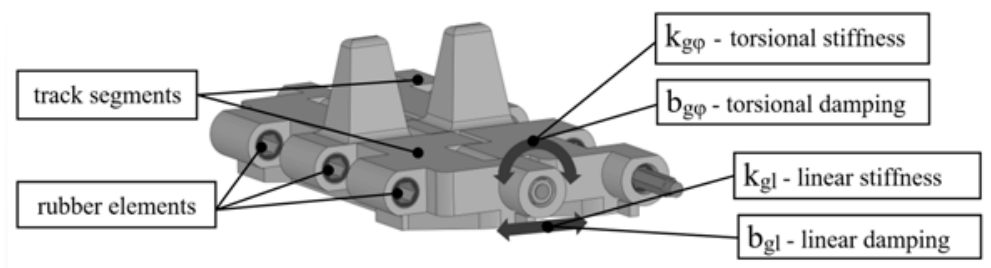

Fig. 1. Physical model and parameters describing forces in the track system

(*) Tekst artykułu w polskiej wersji językowej dostępny w elektronicznym wydaniu kwartalnika na stronie www.ein.org.pl 
method of modifying a four-wheeled armoured vehicle suspension to maximize the vehicle post-firing mobility, minimizing the driver's seat vertical acceleration at the same time. Issues related to the control of rotary shock-absorbers in the tracked vehicle suspension, aiming to improve the vehicle stabilization efficiency, are presented in [12]. The basic sources of dynamic loads acting on combat vehicles, resulting from off-road riding, firing the cannon, being hit by the enemy's projectile or the effect of explosives, are presented in [19]. The methodology of the tracked vehicle modelling using multibody dynamics simulations is applied in [13], where results of a numerical analysis performed in the LMS Virtual.Lab Motion environment are presented and compared to experimental testing results. The assessment of the conditions of comfort of persons carried in selected special vehicles is presented in [11]. A failure to meet the criteria concerning the human body exposure to vibrations caused by the vehicle motion may lead to serious perception disturbances and hinder the crew's performance. In [3] a model is presented of controlling an active suspension system using the Linear Quadratic Regulator (LQR) technique to improve the crew's comfort. Report [15] makes a survey of the functionality of the vehicle motion modelling software using multibody dynamics simulations, where functions of programs facilitating the tracked vehicle model construction, together with the possibility of conducting an analysis taking account of the ground deformability, are described.

The authors of this paper put forward a method of estimating parameters describing the track system operation based on genetic algorithms and taking account of the vehicle kinematic quantities recorded during experimental tests. The issues presented herein comprise an analysis of the impact of contact forces in kinematic pairs between the track segments and of the effect of the track tension degree realized by the setting of the tensioning wheel. The final part of the paper

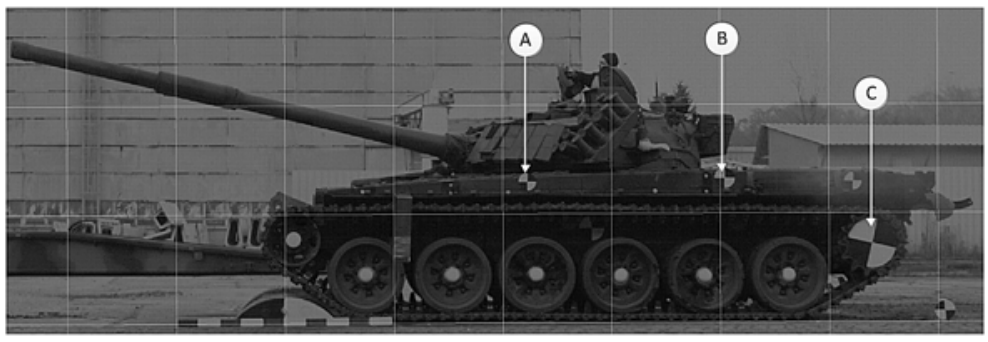

Fig. 3. On-vehicle marker location (X, Y); A (-3347, 587), B (-1445, 620), C (0, 0)

a)

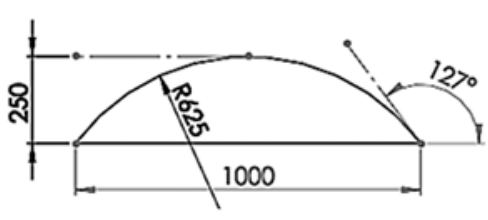

Fig. 4. Obstacle geometry (a) and location on the testing site (b)

track system parameters. The obstacle geometry is created based on existing elements of a track intended for long-distance testing that will be the subject of further analyses in this respect. The tests were conducted at the vehicle speed of 4,8 and $13 \mathrm{~km} / \mathrm{h}$. For statistical purposes, each run was repeated three times. Example results of the testing are presented and compared to the results of numerical analyses in section 5 .

\section{Tracked vehicle mathematical model}

IDENTIFICATION OF THE TRACK SYSTEM PARAMETERS BY TESTING

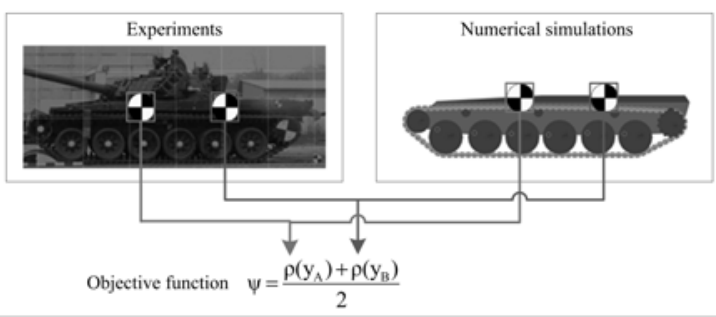

SELECTION OF DYNAMIC CHARACTERISTICS FOR THE TRACK SYSTEM (SELECTION OF DAMPING VALUES)

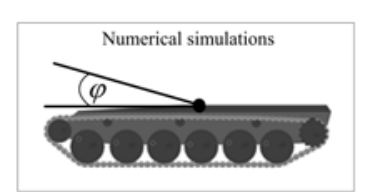

Objective function $\quad \psi=\operatorname{var}(\varphi(t))$

Based on geometrical data and mass-inertia parameters, a tracked vehicle model was constructed using the multibody dynamics simulation method implemented in the ADAMS package. The model takes account of the track system, the suspension subassemblies connected by kinematic pairs, spring and damping elements as well as the vehicle deflection limiters (Fig. 5).

The dynamics of multibody systems in the MSC ADAMS environment is modelled by defining the coordinates of kinematic bodies and the type of kinematic constraints, as well as specifying mass-inertia parameters and param-

Fig. 2. Flowchart of works performed within the paper

presents the criterion for selecting optimum damping values of shockabsorbers installed in the vehicle under consideration (cf. Fig. 2).

\section{Experimental testing}

The aim of experimental tests of the vehicle passage over a field obstacle was to determine the trajectory of markers on the vehicle body (on the sprung mass). The tests resulted in characteristics of linear displacement, velocity and acceleration in points located on the body and marked as shown in Fig. 3.

The tests were carried out using a prototype of the PT-91 Twardy vehicle. The photogrammetric method of image recording was applied using a PHANTOM V9.1 high-speed wide-angle lens camera. The vehicle mass during the experimental tests totalled $42600 \mathrm{~kg}$ estimated based on the lack of any equipment elements.

The tests included instances of passage over an obstacle (cf. Fig. 4) attacked by the vehicle with both tracks at the same time. The proposed variant of passing over the obstacle is used to identify the eters of contact between the system elements. Moreover, the computation process parameters are declared, such as: integration step, simulation time, initial velocity, etc.

The vehicle model is simplified by taking account of the longitudinal plane of symmetry. It is made of 118 non-deformable elements connected to each other by kinematic pairs into a kinematic chain.

The system theoretical mobility is determined using the GrüblerArtobolevsky formula for spatial systems:

$$
W_{T}=6 k-\sum_{i=1}^{5}(6-i) p_{i}
$$

where:

$W_{t} \quad$ - system theoretical mobility,

$k \quad$ - number of moving kinematic bodies,

$p_{i} \quad$ - number of $\mathrm{i}$-th class kinematic bodies. 


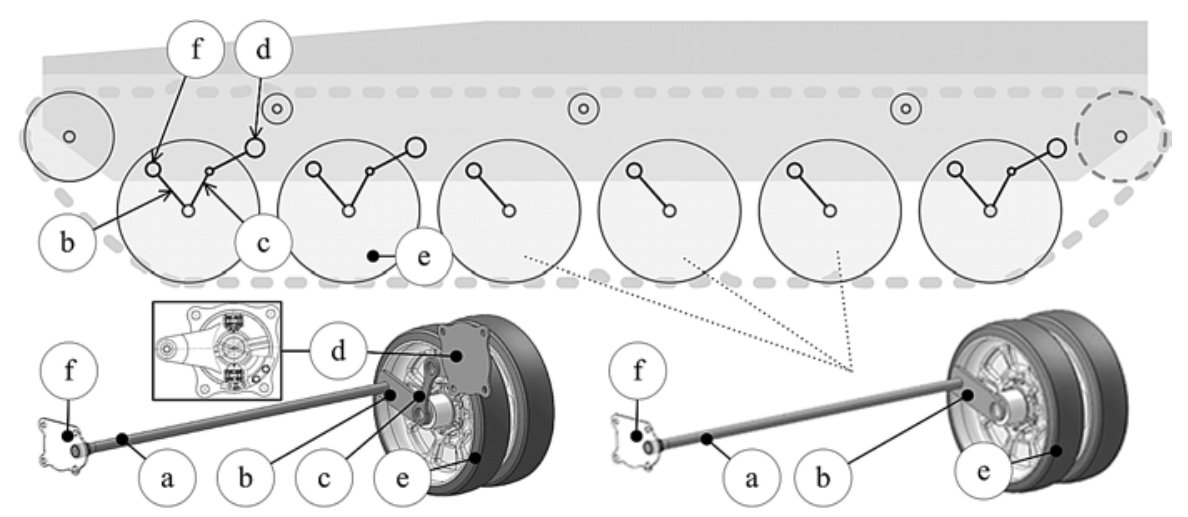

Fig. 5. Kinematic diagram of the PT-91 vehicle suspension: a) torsion bar; b) rocker; c) rocker - shockabsorber link; d) rotary vane damper; e) ground wheel; f) torsion bar socket vehicle kinematics and dynamics mechanisms applied in the MSC ADAMS software can be found in [1].

\section{Estimation of the model param- eters}

One of the factors that have an impact on dynamics and the suspension system efficiency is the force acting on the vehicle wheels, which results from the track tension. The track tension is adjusted by changing the tensioning wheel position. It is also important to take account of the track wear, which is mainly due to the wear of rubber elements affecting the system performance.
Substitution of respective values gives the following result:

$$
W_{T}=6 * 118-5 * 18-4 * 2-3 * 3=601
$$

The vehicle model created by means of the multibody dynamics simulation method requires a definition of generalized coordinates:

$$
\mathrm{q}=\left[\mathrm{q}_{1}+\mathrm{q}_{2}+\ldots+\mathrm{q}_{\mathrm{n}}\right]
$$

Kinematic bodies are limited by constraint equations which can be written as follows:

$$
(\mathrm{q}, \mathrm{t})=\left[\Phi_{1}\left(\mathrm{q}_{1}, \mathrm{t}\right), \ldots, \Phi_{\mathrm{n}}\left(\mathrm{q}_{\mathrm{n}}, \mathrm{t}\right)\right]^{\mathrm{T}}
$$

The motion equation written in the first-order Lagrangian formalism can be expressed using the following vector notation:

$$
\mathrm{M} \ddot{\mathrm{q}}+\Phi_{\mathrm{q}}^{\mathrm{T}} \lambda=\mathrm{Q}
$$

where:

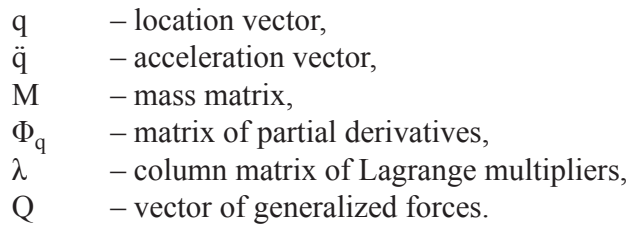

Considering the transformations resulting from the occurrence of velocity constraints expressed as local coordinates $\left(\gamma=\Phi_{q} \ddot{q}\right)$ in the equations, the expressions making up a system of the first-order Lagrangian equations can be presented in the following form:

$$
\left[\begin{array}{cc}
\mathrm{M} & -\Phi_{\mathrm{q}}^{\mathrm{T}} \\
\Phi_{\mathrm{q}} & 0
\end{array}\right]\left[\begin{array}{l}
\ddot{\mathrm{q}} \\
\lambda
\end{array}\right]=\left[\begin{array}{l}
\mathrm{Q} \\
\lambda
\end{array}\right]
$$

The presented equations of the system motion constitute a system of differential-algebraic equations composed of first-order differential equations with an independent variable in the form of time and algebraic constraint equations. The system of equations is determined through numerical integration, i.e. the solution is found with set accuracy at discrete time instants. The most popular numerical integration method in the MSC ADAMS software package is based on the backward difference formula (the Gear algorithm). A detailed description of the mathematical model and of the methods of computing the

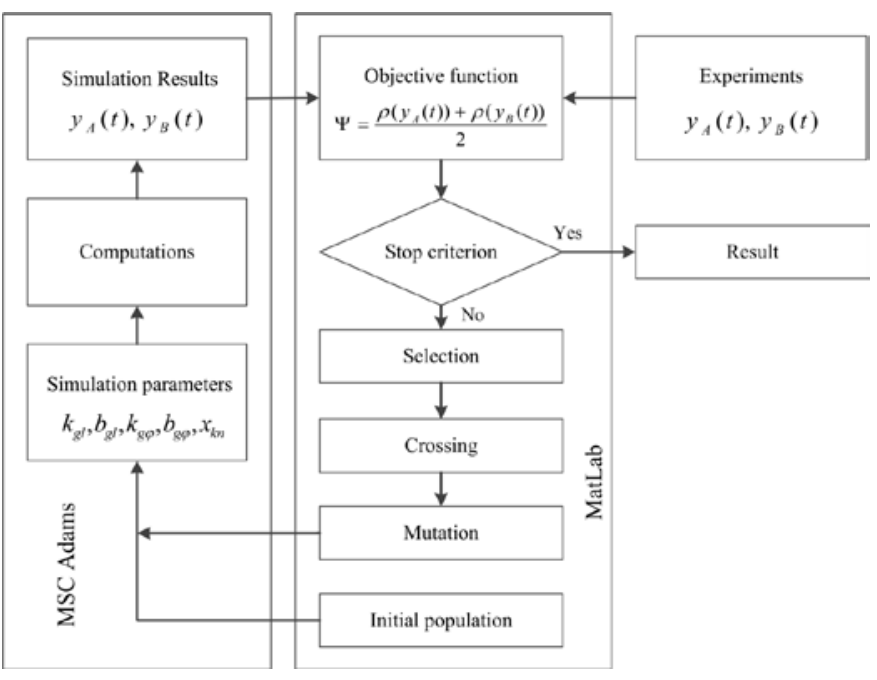

Fig. 6. Program flowchart

Apart from the tensioning wheel setting, the track system properties within the model are described by the following quantities: linear stiffness and linear damping as well as torsional stiffness and torsional damping of the track segment links (cf. Fig. 1).

The results obtained from experimental testing were used to adjust the tracked vehicle model parameters. For this purpose, an original in-house program was developed that couples simulations of the tested vehicle runs to the genetic algorithm included in the MatLab program optimization module. The program flowchart is presented in Fig. 6. The genetic algorithm efficiency is highly dependent on its objective function, being the index of the model behaviour similarity compared to the real object.

There are many statistical indices defining the degree of the model similarity to empirical data. In this paper, an analysis is applied of correlations needed to construct the objective function by specifying the correlation coefficients.

The correlation between two random variables $\mathrm{X}$ and $\mathrm{Y}$ is a measure of the force (level) of the linear relation between the variables [8]:

$$
\rho=\frac{\operatorname{cov}(X, Y)}{\sigma_{X} \sigma_{Y}}
$$

where covariance of variables $\mathrm{X}$ and $\mathrm{Y}$ occurs in the numerator:

$$
\left.\operatorname{cov}(X, Y)=E\left[\left(X-\mu_{X}\right) Y-\mu_{Y}\right)\right]
$$


where:

$\mu_{\mathrm{X}}$ and $\mu_{\mathrm{Y}} \quad$-arithmetic means of $\mathrm{X}$ and $\mathrm{Y}$ within the population, $\sigma_{X}, \sigma_{Y} \quad-$ standard deviations of variable $\mathrm{X}$ and $\mathrm{Y}$.

Coefficient $\rho$ is included in the interval $\langle-1 ; 1\rangle$. If $\rho=0$, the variables are non-correlated. If $\rho=-1$, regression lines exhibit a negative inclination, which means that negative correlation is found. If $\rho=1$, the reverse is the case, which means that correlation is positive [8].

The correlation coefficient described above was used to determine the index of similarity between the curves illustrating changes in linear displacement of the markers on the model body obtained from simulations and those obtained by means of video recording of the vehicle test run.

Markers A and B on the vehicle body (cf. Fig. 3) were used to compare the model to the experiment result.

Next, a column matrix was defined of design variables and intervals thereof which enable carrying out the simulation computation process and which are consistent with the design technological determinants:

$$
\mathrm{x}=\left\{\mathrm{x}_{1}, \mathrm{x}_{2}, \mathrm{x}_{3}, \mathrm{x}_{4}, \mathrm{x}_{5}\right\}
$$

where:

$$
\begin{gathered}
\mathrm{x}_{1}=\mathrm{k}_{\mathrm{gl}}, \quad \mathrm{k}_{\mathrm{gl}} \in[1.0 \mathrm{e}+5 ; 1.0 \mathrm{e}+9] \\
\mathrm{x}_{2}=\mathrm{k}_{\mathrm{g} \varphi}, \mathrm{k}_{\mathrm{g} \varphi} \in[10 ; 1.0 \mathrm{e}+5] \\
\mathrm{x}_{3}=\mathrm{b}_{\mathrm{gl}}, \quad \mathrm{b}_{\mathrm{gl}} \in[1 ; 1.0 \mathrm{e}+6] \\
\mathrm{x}_{4}=\mathrm{b}_{\mathrm{g} \varphi}, \quad \mathrm{b}_{\mathrm{g} \varphi} \in[1 ; 1.0 \mathrm{e}+5] \\
\mathrm{x}_{5}=\mathrm{x}_{\mathrm{kn}}, \quad \mathrm{x}_{\mathrm{kn}} \in[-5590.0 ;-5550.0]
\end{gathered}
$$

where:

$\mathrm{k}_{\mathrm{gl}}-$ linear stiffness of the track segment link $\left[\frac{\mathrm{N}}{\mathrm{m}}\right]$

$\mathrm{k}_{\mathrm{g} \varphi}-$ torsional stiffness of the track segment link $\left[\frac{\mathrm{Nm}}{\mathrm{rad}}\right]$

$\mathrm{b}_{\mathrm{gl}}$ - linear damping coefficient of the track segment link $\left[\frac{\mathrm{N}^{*} \mathrm{~s}}{\mathrm{~m}}\right]$

$\mathrm{b}_{\mathrm{g} \varphi}-$ torsional damping coefficient of the track segment link $\left[\frac{\mathrm{Nm}^{*} \mathrm{~s}}{\mathrm{rad}}\right]$

$\mathrm{x}_{\mathrm{kn}}-$ tensioning wheel setting [mm]

The estimation process using the optimization procedure was carried out based on the simulation of the vehicle run over the obstacle with the speed of $4 \mathrm{~km} / \mathrm{h}$. The objective function was defined in the form of the arithmetic mean of correlation coefficients of vertical displacement of markers A and B:

$$
\Psi=\frac{\rho\left(\mathrm{y}_{A}(\mathrm{t})\right)+\rho\left(\mathrm{y}_{B}(\mathrm{t})\right)}{2}
$$

where:

$\mathrm{y}_{A}(\mathrm{t})$ - marker A vertical displacement,

$\mathrm{y}_{B}(\mathrm{t})$ - marker $\mathrm{B}$ vertical displacement,
The following optimization parameters were established:

- population size $=40$

- stop criterion: number of generations $=30$. ables:

The calculations gave the following values of the design vari-

$$
\begin{gathered}
\mathrm{k}_{\mathrm{gl}}=2.676 \mathrm{e}+7\left[\frac{\mathrm{N}}{\mathrm{m}}\right] \\
\mathrm{k}_{\mathrm{g} \varphi}=6.257 \mathrm{e}+3\left[\frac{\mathrm{Nm}}{\mathrm{rad}}\right] \\
\mathrm{b}_{\mathrm{gl}}=1.0 \mathrm{e}+4\left[\frac{\mathrm{N}^{*} \mathrm{~s}}{\mathrm{~m}}\right] \\
\mathrm{b}_{\mathrm{g} \varphi}=7.74 \mathrm{e}+3\left[\frac{\mathrm{Nm} * \mathrm{~s}}{\mathrm{rad}}\right] \\
\mathrm{x}_{\mathrm{kn}}=-5563[\mathrm{~mm}]
\end{gathered}
$$

\section{Testing results}

The numerical and experimental results are shown and compared to each other in the charts below. The charts present curves illustrating time-dependent changes in the vehicle body displacement, velocity and acceleration in relation to the global system of coordinates.

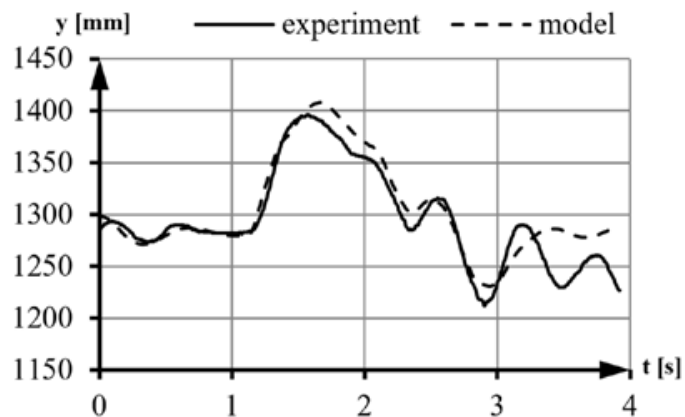

Fig. 7. Curves illustrating time-dependent changes in vertical displacement of marker $A$

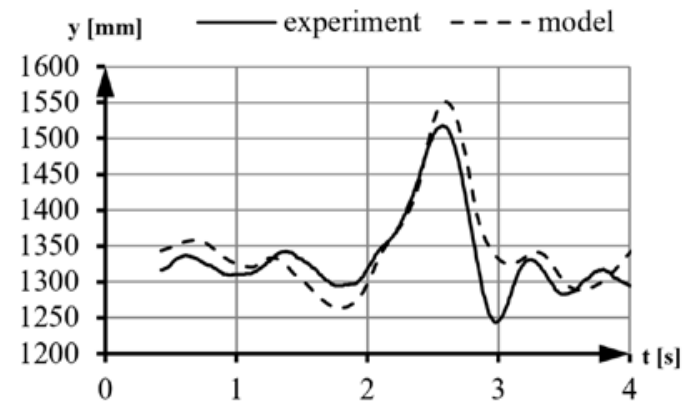

Fig. 8. Curves illustrating time-dependent changes in vertical displacement of marker $B$

The presented curves were plotted for the run speed of $13 \mathrm{~km} / \mathrm{h}$. The correlation coefficients of marker A and marker B vertical displacement $-\rho\left(y_{A}(t)\right)$ and $\rho\left(y_{B}(t)\right)-$ in the case of the model are 0.94 and 0.87 , respectively. 


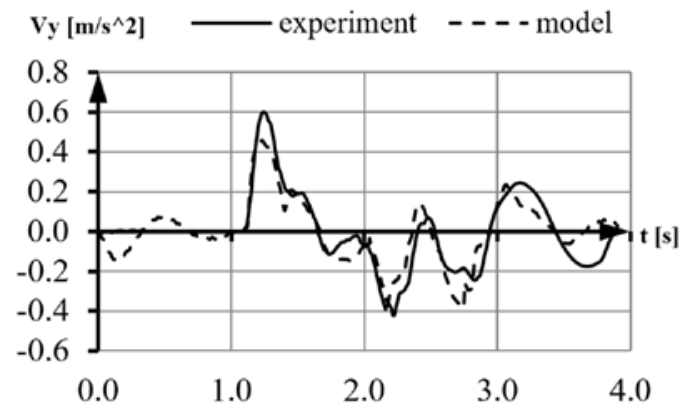

Fig. 9. Curves illustrating time-dependent changes in marker A velocity in the vertical direction

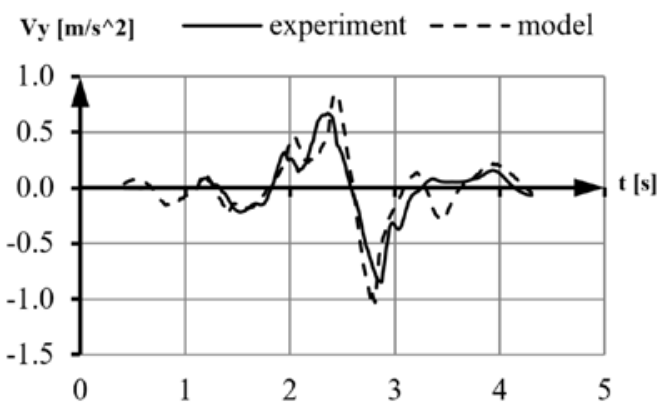

Fig. 10. Curves illustrating time-dependent changes in marker B velocity in the vertical direction

ay $\left[\mathrm{m} / \mathbf{s}^{\wedge} \mathbf{2}\right] \longrightarrow$ experiment $\quad----$ model

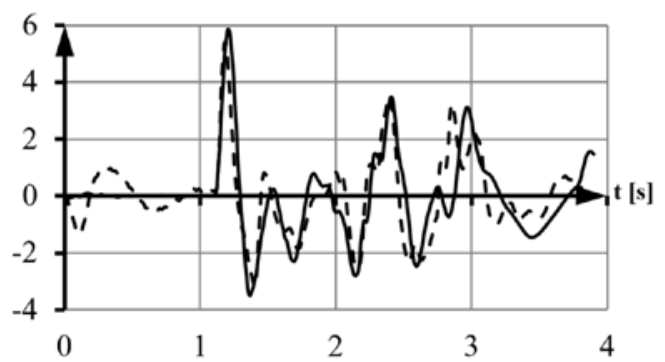

Fig. 11. Curves illustrating time-dependent changes in marker A acceleration in the vertical direction

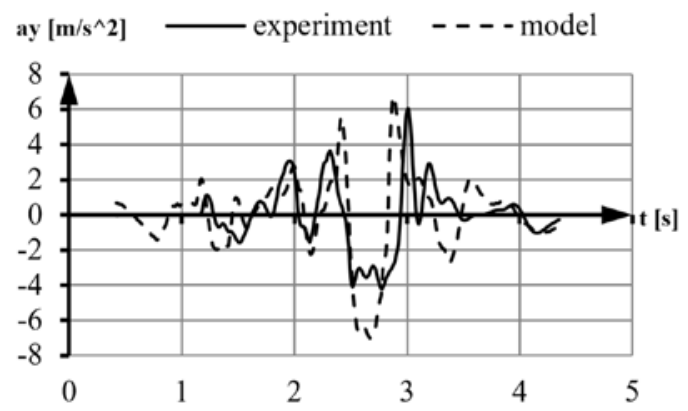

Fig. 12. Curves illustrating time-dependent changes in marker B acceleration in the vertical direction

The velocity characteristics obtained by means of numerical simulations demonstrate high convergence with the experiment, both qualitatively and quantitatively. The maximum velocity values for points A and B are found at the level of 0.6 and $0.8 \mathrm{~m} / \mathrm{s}$, respectively. In this case, instantaneous acceleration reaches the value of $6 \mathrm{~m} / \mathrm{s}^{2}$.

\section{Selection of the shock-absorber damping values}

The tracked vehicle model treated as a dynamic system enables an analysis of characteristics such as transfer function or frequency curves.

The two characteristics are dependent on the properties of the system itself, but they are independent of the kind of the input functions applied thereto. In practice, the suspension optimal parameters are selected using methods of the statistical theory of springing, which involves determination of numerical characteristics of the road and off-road bumps distribution, such as the mean value, variance or standard deviation. The measured terrain samples are then classified into groups. An example classification may be the effect of the division of the terrain irregularities (with respect to specific standard deviation for example) into groups such as roads with slight irregularities, dirt roads and very bumpy roads. Owing to that, it is possible to generate a random function describing the terrain profile. There are studies concerning determination of numerical characteristics of the irregularity distribution of terrains for which special vehicles are designed. However, their findings are not disclosed to the public. Therefore, a method was put forward [4] of the damping value selection through an analysis of the variance of the body longitudinal inclinations $\Psi=\operatorname{var}[\varphi(t)]$ at a specific input function acting on the vehicle depending on its velocity [4].

For this purpose, an input function model was used in the form of a field obstacle as presented in Fig. 3. Analyses were conducted of the developed vehicle model in variants taking account of the change in the speed of the vehicle attack on the obstacle and the change in the damping value in shock-absorbers. Each simulation lasted $15 \mathrm{~s}$. In every case, velocity ranged from 5 to $55 \mathrm{~km} / \mathrm{h}$ and the simulations were performed with the step of $5 \mathrm{~km} / \mathrm{h}$. The analyses were conducted for different values of the damping coefficient, according to the variants listed in Table 1.

Based on that, the velocity-dependent vehicle body variance of longitudinal inclinations $\boldsymbol{\Psi}=\operatorname{var}[\boldsymbol{\varphi ( t )}]$ was determined (cf. Fig. 13).

Analysing the results, it can be observed that the variance of the body longitudinal inclinations illustrated by curve 4 is low for the entire range of the velocities under analysis. However, the damping value selection is also dependent on the vehicle purpose and determination of the velocity criterion for which the vehicle should exhibit smaller variance of the body longitudinal inclinations [5].

\section{Conclusions}

The photogrammetric method made it possible to obtain results in the form of curves illustrating changes in displacement, velocity and acceleration of selected points of the tracked vehicle suspension body, which constituted the basis for verification of the assumptions adopted in the modelling process. The data obtained in this way were used for

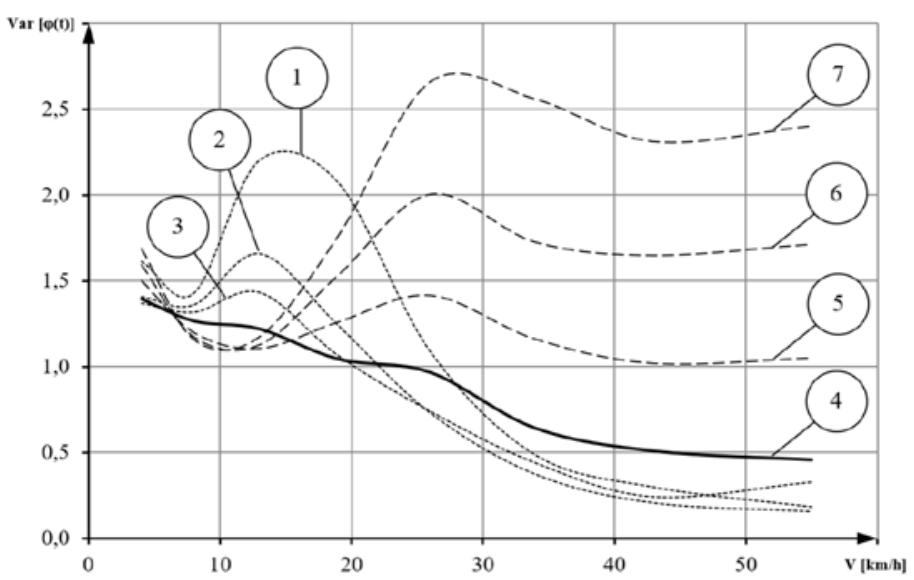

Fig. 13. Curves illustrating variance of the vehicle body longitudinal inclination depending on the vehicle velocity for different damping values 
Table 1. Variants of performed simulations

\begin{tabular}{|c|c|c|c|c|c|c|c|}
\hline Curve number & 1 & 2 & 3 & 4 & 5 & 6 & 7 \\
\hline $\begin{array}{c}\text { Damping in shock-ab- } \\
\text { sorbers [Nm*s/rad] }\end{array}$ & 0 & 11272 & 22545 & 45090 & 90180 & 135270 & 180360 \\
\hline
\end{tabular}

the purposes of the objective function in the procedure of the model parameter estimation. The developed model of the tracked vehicle described herein was adjusted through estimation of the parameters describing the forces occurring in the track system. The vehicle body displacement, velocity and acceleration results obtained numerically and experimentally are highly convergent.

A universal method has thus been developed of selecting the track system parameters which are difficult to establish otherwise. The method can be applied in modelling dynamic phenomena in tracked vehicles and in the selection of operating parameters, such as the track tension degree or the damping value in shock-absorbers.

It also enables an analysis of phenomena occurring in wheeled vehicles, to identify the parameters of the tyre model for example.

Scientific work conducted under Contract 2828/B/T00/2010/40, financed from budgetary means for science in the years 2011-2014 as Research Project O N501 282840.

\section{References}

1. ADAMS Standard Documentation and Help, MSC Software Corporation, MD/ADAMS R3, 2007.

2. Automotive Research Center. Dynamic analysis and design of tracked vehicles http://arc.engin.umich.edu/events/archive/annual/conf98/ case2.pdf, 16.05.2016.

3. Bello M M, Shafie A A, Khan R M. Off-Road Vehicle Suspension Performance Improvement Using Linear Quadratic Regulator, Techniques. International Conference on Mechanical and Industrial Engineering (ICMAIE'2015), Kuala Lumpur, Malaysia 2015.

4. Burdziński Z. Teoria ruchu pojazdu gąsienicowego [Theory of the tracked vehicle motion]. Warszawa: Wydawnictwa Komunikacji i Łączności, 1972.

5. Chodkowski A. W. Konstrukcja i obliczanie szybkobieżnych pojazdów gąsienicowych [Design and calculation of high-speed tracked vehicles]. Warszawa: Wydawnictwa Komunikacji i Łączności, 1990.

6. Choi E, Ryoo J, Cho J. et al. Optimum suspension unit design for enhancing the mobility of wheeled armoured vehicles. Journal of Mechanical Science and Technology 2010; 24: 323-330, http://dx.doi.org/10.1007/s12206-009-1102-0.

7. Dhir A, Sankar S. Assessment of tracked vehicle suspension system using a validated computer simulation model. Journal of Terramechanics 1995; 32(3): 127-149, http://dx.doi.org/10.1016/0022-4898(95)00012-7.

8. Dietrich C F. Uncertainty, Calibration and Probability: The statistics of scientific and industrial measurement 2nd edition. Boca Raton: Taylor \& Francis Group, 1991.

9. Djurić R, Milisavljević V. Investigation of the relationship between reliability of track mechanism and mineral dust content in rocks of lignite open pits. Eksploatacja i Niezawodnosc - Maintenance and Reliability 2016; 18(1): 142-150, http://dx.doi.org/10.17531/ein.2016.1.19.

10. Hulbert G M. et al. Case Study for network-distributed collaborative design and simulation: extended life optimization for M1 Abrams tank road arm. Mechanics of Structures and Machines 1999; 27(4): 423-451, http://dx.doi.org/10.1080/08905459908915706.

11. Jamroziak K, Kosobudzki M, Ptak J. Assessment of the comfort of passenger transport in special purpose vehicles. Eksploatacja i Niezawodnosc - Maintenance and Reliability 2013; 15 (1): 25-30.

12. Kciuk S, Duda S, Mężyk A, Świtoński E, Klarecki K. Tuning the Dynamic Characteristics of Tracked Vehicles Suspension Using Controllable Fluid Dampers. Innovative Control Systems for Tracked Vehicle Platforms. Studies in Systems, Decision and Control 2. Springer 2014; $243-258$.

13. Kciuk S, Mężyk A, Mura G. Modelling of tracked vehicle dynamics. Journal of KONES Powertrain and Transport 2010; $17(1)$ : $223-232$.

14. Kunsoo H, Jungtak K, Hong D. Estimation of dynamic track tension utilizing a simplified tracked vehicle model. American Control Conference, 2001. Proceedings of the 2001, Arlington, VA, 2001; 5: 3335-3340, http://dx.doi.org/10.1109/acc.2001.946143.

15. Madsen J, Heyn T, Negrut D. Methods for Tracked Vehicle System Modelling and Simulation. Technical Report 2010-01.

16. Mężyk A. et al. Modelling and investigation of dynamic parameters of tracked vehicles. Mechanics and Mechanical Engineering 2011; 15(4): 115-130.

17. Ogorkiewicz R M. Technology of Tanks: Volumes I and II. Surrey: Jane's Information Group, 1991.

18. Qigang S, Hongyan W, Li Y. Design of the refitted high mobility tracked vehicle suspension system. 2009 International Conference on Mechatronics and Automation, Changchun, 2009; 4638-4643, http://dx.doi.org/10.1109/ICMA.2009.5244787.

19. Rybak P. Operating loads of impulse nature acting on the special equipment of the combat vehicles. Eksploatacja i Niezawodnosc Maintenance and Reliability 2014; 16 (3): 347-353.

20. Sankar S S, Dhir A A, Shankhla V S. Simulation and field testing of tracked vehicle suspension dynamics. ASME. J. Dyn. Sys., Meas., Control, 1994; 116(4): 764-773.

21. Shengii Y, Daolin X. An application of a progressive neural network technique in the identification of suspension properties of tracked vehicles. Proceedings of the 9th International Conference on Neural Information Processing ICONIP '02, 2002; 2: 542-546, http://dx.doi. org/10.1109/ICONIP.2002.1198115.

22. Xu D, Yap F F, Han X, Wen G L. Identification of spring-force factors of suspension systems using progressive neural network on a validated computer model. Inverse Problems in Engineering, 2003; 11(1): 55-74, http://dx.doi.org/10.1080/1068276021000020177.

\section{Jacek GNIŁKA \\ Arkadiusz MĘŻYK}

Institute of Theoretical and Applied Mechanics,

Silesian University of Technology

Faculty of Mechanical Engineering

ul. Konarskiego 18A, 44-100 Gliwice, Poland

E-mails: jacek.gnilka@polsl.pl, arkadiusz.mezyk@polsı.pl 